\title{
Designing an educational tool to revitalise woven textile mending
}

\begin{tabular}{|r|l|}
\hline Journal: & Research Journal of Textile and Apparel \\
\hline Manuscript ID & RJTA-06-2017-0027.R1 \\
\hline Manuscript Type: & Original Manuscripts \\
\hline Keyword: & Woven Fabric, Wool, Stitch Structure, Design \\
\hline \multicolumn{2}{|l}{} \\
\hline
\end{tabular}

SCHOLARONE ${ }^{m}$

Manuscripts 


\section{Introduction}

Fabric mending is a valuable yet frequently overlooked skill that involves fixing various faults that may occur in fabrics. Its applications can be found in a purely domestic context as well as in a textile manufacturing setting. However, due to the current economic and cultural backdrop, this form of needlecraft is on the brink of disappearing, with older generations not being able to pass on their knowledge of the skill. While the demand for the skill is still present in certain settings, such as textile manufacturing mills and smaller scale textile micromanufacturing businesses, the availability of literature and learning resources is limited relating to this particular craft.

The project was carried out in collaboration with a vertical woollen weaving mill, located in in West Yorkshire. The company is proud to be one of the last remaining vertical mills in the UK, meaning that it carries out virtually every woollen spinning and weaving textile manufacturing process on the same premises.

\section{Research aims and objectives}

The aim was to investigate and understand the mending process within the industrial context, focussing on woven woollen fabrics, and to produce a suitable tool that could be used to document and revitalise the mending processes and to teach the skill.

To achieve this aim, the following objectives were determined:

\section{Research Objectives}

- To perform secondary research regarding mending practice within woollen weaving textile manufacturing industry and why it is needed as well as to pinpoint the reasons for the reduced degree of this practice.

- To interview relevant staff from the mending and burling department at the mill to determine the purpose and the level of mending within the industrial context as well as to learn more about the informants' background and experience.

- To use the findings from primary and secondary research to identify the most efficient methods and principles to teach skills, that could be incorporated in the development of an educational video tool. 
- To film a video to capture mending processes within the mill to document, revitalize and pass on the skills.

- To create diagrams that could be used to visually simplify the pattern and accelerate the acquisition of pattern recognition skills.

- To test the instructional video tool for its effectiveness and accuracy and evaluate the findings.

\section{Definition of mending}

Textile mending is a needle based skill that involves fixing various faults that may occur in fabrics. Its applications can be found in purely domestic context as well as in textile manufacturing setting. Therefore, textile mending may refer to minor repairs that can be performed at home on various textile products as well as to highly skilled, undetectable reconstruction of fabric through invisible mending carried out by professional craftspeople in workshops. This dissertation will primarily focus on mending that occurs in a textile manufacturing setting, specifically woollen weaving mills, where mending is used to repair imperfections that appear during different production processes. Freshly woven fabrics often have imperfections that occur during various cloth production processes which cause severe profit losses for textile manufacturers. As a result, to comply with the company's set standards, woven textiles undergo a careful inspection process throughout which all weaving defects are marked out and then repaired by hand. This inspection process involves three main operations: perching, burling and mending, with all of them performed prior to textile finishing procedures (Karmakar, 1999).

\section{Perching}

Perching refers to the visual inspection of fabric done by the human eye. The cloth is pulled over the frame, which is made from frosted glass and is simultaneously lit from behind and above to highlight the defects in the fabric. The objective is to search for faults that could have been caused by carding, spinning, warping or weaving processes. As the fabric is pulled metre by metre across the perch, flaws such as stains, knots, small holes, missing warp or weft yarns, as well as other imperfections, are marked. 
This is an important stage as not only does it assess the quality of the already woven cloth but also helps to detect the origins of the faults within the production line, and therefore prevent them. In order to achieve this, specialists from other production departments should be brought together as soon as possible to evaluate the faults in the piece and discuss how they could be avoided. The fast work pace in perching is crucial, otherwise looms may carry on weaving faulty pieces, adding extra manufacturing costs, labour and time needed to correct them (Lyness and Murphy, 1955).

The pieces that contain only minor defects can be marked by passing a piece of thread or string through a selvage parallel to the fault. While the manufacturer receives an allowance for a certain number of strings, this still reduces profits for the seller. However, in the cases of large numbers of flaws present within the piece, the fabric may have to be discarded or sold at an extremely low price (King and Lester, 1932).

\section{Burling}

Following perching, the marked cloth is passed on to burlers and menders to repair the fabric defects. Burling can be described as the process of removing any remaining foreign matter in the fabric such as burrs (vegetable matter including leaves, seeds, and twigs), yarn knots or thinning out slubs (lumpy or thick places in yarn). This type of correction is mainly applicable to woollen, worsted, spun rayon and cotton fabrics and is done by hand using tweezers called 'burling irons'.

\section{Figure 1 here.}

\section{Mending}

Mending involves the actual repair of imperfections such as weaving in a missing warp or weft yarn with a hand needle and repairing tears as well as small holes. For this task, a needle with a ball-point is used as it is still able to penetrate the fabric structure, but the blunt tip prevents the needle from tearing through the fibres in the weave (Stewart, 2009).

\section{Figure 2 here.}


According to the "Systematic Training for Burlers and Menders Manual", the physical requirements for this occupation were to have good eyesight (including colour vision), possess an above average pattern perception and good finger dexterity (The Wool, Jute and Flax Industry Training Board, 1975). Overall, it is not perceived as an easy job as it is very hard on the eyesight and has a monotonous nature. Additionally, one account mentions that burlers and menders had a tendency to suffer from bad skin complaints due to continuous action of the forearms passing over the cloth.

\section{The Effect of Technological developments}

Technological developments within the textile industry have been very substantial, particularly since 1967, having a huge impact on machine and labour productivity, quality, costs, and services. These technological advances have allowed the modern weaving processes to become highly automated with most of the adjustment mechanisms being controlled electronically. This has enabled many faults to be repaired prior to or during the weaving process without needing to involve the operatives. Therefore, the overall progress in woollen manufacturing technology is directly accountable for the reduced labour and production costs as well as the improved quality of the textile goods (Horrocks and Anand, 2000).

\section{Why should mending be revitalised and where could it be used?}

Traditional crafts and practices rooted in local knowledge and culture are part of cultural heritage and should be preserved and revitalized (Tung, 2012). However, due to transformative technological change in textile industries that was powered by demographic growth and economic expansion, computer powered looms have become the ultimate solution in textile mills. This, however, has removed the link between the craftsperson and the product, devaluing traditional textile skills and training methods within an industrial context. Conversely, handcraft production is frequently associated with low standard of living due to lack of economic opportunities and minimal competitive advantages. This poses a problem in finding a way to rescue a traditional practice that could adjust to the demographic and economic changes of the present day (Rusu, 2011). 


\section{Modern strategic learning approaches in passing on skills}

Even though there is an increasing interest in learning and teaching crafts as well as skilled practices, obtaining adequate training resources can be problematic. A recent survey carried out by Heritage Crafts Association highlights that access to training for individuals who aspire to make a living through crafts or wish to improve their skills is limited to short courses and workshops, having little to offer in terms of formal or structured learning. Wood (2009) remarked that it is important to comprehend what actually must be learned in order to successfully present a craft teaching method. However, it has been noted that academic resources that provide structures for learning different craft practices have gaps, while studies that focus on interactional methods of teaching crafts are limited (Koskinen et al., 2015). What's more, projects aiming to record the working practices of craftspeople frequently lack systematic methods or insights that are effective while learning (Wood et el., 2009). Furthermore, the numbers of expert craftsmen are diminishing rapidly, with many of them either retiring or moving on to other careers. This reduces both the availability of possible live learning sources and diminishes the quality of the learning (Holmberg, 2013).

\section{Difficulty in articulating tacit knowledge}

When asked to explain complex craft techniques, skilled practitioners have a tendency to give brief responses and minimal, oversimpified descriptions of their actions. As these skills or craft practices often involve various elements of internalised tacit knowledge that have been gathered over a long period of time, the craft professionals can be expected to struggle to put it into words. Additionally, routinely performed tasks seem to be challenging to express verbally as it is not easy to communicate one's actions when the movements follow habitual patterns of execution without thinking (Torell, 2014). Holmberg (2013) noticed a similar occurrence at Handarbetets Vänner, the Swedish handicraft and textile workshop. To train the new members the experienced craftsmen have to assume a teacher's position, however, there is no guidance on how the teaching should be implemented, with one of the craftsmen expressing it as, "Suddenly you are a teacher" (Holmberg, 2013). Nevertheless, Torell (2014) suggests that the more the crafts expert concentrates his or her attention on bodily sensations while in the act of making, these sensory 
observations could be reflected on and then articulated in a more comprehensive way to a learner.

In her research, Wood (2009) investigated the capturing and teaching of the skilled knowledge of master craftsman through the expert learner, an individual who had experience in similar craft fields and had the capacity to learn new skills with minimal instruction. Accordingly, it was noticed that the presence of expert learners during the skill extraction process could assist in identifying gaps in understanding between the learner and the skilled craftsman. Whilst the craftsman struggled to vocalise what he was doing during the initial demonstrations, once the expert learner had gained some basic experience she was able to question the expert more specifically and direct the expert's guidance to the particular actions she was struggling with (Wood et al., 2009).

One study conducted on children learning origami showed that the instructions presented in the moving image format gave better performance results than those that used still images. Another study evaluated the same media with young adults who were learning to tie knots with scoubidou threads. The results reiterated that the better executions were achieved through the instructions given using video rather than still images. Additionally, it was noted that based on their subjective opinion, the participants considered video instructions to be easier to understand and follow than those that were based on the still images (Ganier, Vries, 2016). Furthermore, when assessing the best instruction format for learning first aid, three methods were included: video, still images and a combination of both. The best performance in this study was achieved through following instructions using the hybrid format, while the video only demonstration showed intermediate performance levels, with still images only format showing the poorest results (Ganier and Vries, 2016). In her research, Wood reiterated that video as a learning resource on its own was not a good enough method for acquiring tacit knowledge (Wood, 2003) Regarding the instructions using still images, a source evaluating crochet learning remarked that the images could only display hands, yarn, and the position of the needle at fixed points, without representing the previous actions or how the movement progressed (Lindwall and Ekström, 2012). It was therefore decided that this research would use a combination of video, still images and guidance text to present the instructions on how to mend in the most comprehensible manner. 


\section{Methodology}

To address the aims of this research, a bricolage methodology and qualitative research methods have been employed. Qualitative research methods are particularly suitable for the investigation of tacit and intuitive understandings of cultures and processes, allowing the implementation of research in context and the observation of actions and interactions of individuals (Tracy, 2013). This application of multiple methodologies may be regarded as a bricolage, which acts as a pieced together, cohesive set of practices that provide solutions to a problem in a specific situation (Yee and Bremner, 2011). In this methodology, the selection of tools is not set in advance with 'bricoleur' actively constructing new methods by using creatively what is already available. Hammersley (2004) noted that the 'bricoleur' essentially is self-taught which leads to the ingenuity and novelty of what is produced. This methodology differs from mixed methods or triangulation as the primary intention for the diverse use of methods is to construct new techniques rather than to compliment or validate the work (Roberts and Priest, 2010).

\section{The expert informant}

In order to determine the purpose and the level of mending within the industrial context, relevant staff from the mending and burling department at the mill was selected and interviewed. The main mending informant, was suggested by the management of the mill and was chosen because of her extensive experience and approachability. The initial meeting was set up to present the project to the management and marketing departments of the mill and to ensure that there was mutual understanding regarding the objectives, expectations and limitations was achieved.

\section{Semi-structured interview}

Afterwards, a semi-structured interview was used to collect primary data and to build a foundation for the video planning process. The purpose was to get to know the main informant better and to form an insight into her professional experience. It also aimed to uncover the degree of mending carried out at the mill and the most common fault origins. The format of semi-structured interview was chosen to allow the two-way communication and encourage the informant to lead the discussion, while exploratory indirect questions were asked to guide 
the conversation in the right direction and stimulate its flow (Holmberg, 2013). The interview was conducted using pre-prepared questions and recorded with a Panasonic Lumix G video camera.

\section{Table 1 here.}

\section{Filming}

This research project employed digital video recording and editing methods as digital recording and storage offer superior quality and longevity compared to text materials. Another factor was the accessibility of the format; video recording has become an accessible tool for the non-professional user, which was significant as the researcher was new to the discipline (Shrum, et al. 2005). Employing digital video during the primary data collection allowed for the simultaneous documentation of visual and audio sources, as well as allowing repeated viewings and data manipulation during the postproduction stages (Knoblauch and Schnettler, 2012).

This research employed an ethnographic approach to video recording, selecting situations and actions relevant to the context of the research (Pauwels and Margolis, 2011). Through her research, Wood (2009) noted that employing an ethnographic approach to video making was beneficial in craft learning due to its ability to capture the instructions and teacher and learner interactions, as well as bring the hidden aspects of craft learning to the forefront. She discovered that the use of the video recorded material in craft learning situations is helpful to provide an overview of the complete task (Wood, 2005).

\section{Instructional tool development}

The instructional video was developed in order to record and present the craft practice in a format that would endure and be accessible to anybody who wished to learn. The content of the produced instructional video included the informant's description of the job, necessary tools, introduction to woven pattern structure, and the instructions of different mending techniques used in the mill environment. The framework of this instructional tool was carefully designed using the methods that were found to be effective in transferring the tacit knowledge. The findings from primary and secondary research sources revealed two concepts that were advantageous when teaching mending skills to 
novice learners:

1. Ability to recognize and follow the woven pattern helped to understand the mending process.

2. The participation of a trainee during the tacit knowledge elicitation process helped the teacher to provide more detailed instructions.

Consequently, design technologies were employed to create visual representations of weave structures that could aid in training woven pattern comprehension. Additionally, the process of teaching a trainee was recorded to reveal additional instructions that were suggested by the informant and situations involving potential problem points.

\section{Video script development}

Additional meeting with the informant was arranged to produce a script plan and structure the filming. To achieve this, the following processes were involved:

1. Identifying the faults

The Systematic Training for Burlers and Menders manual (1970) was used as a reference guide as it contained the list of faults that used to occur during woven woollen cloth manufacture. The informant was asked to discuss the faults on the list of one by one and identify which defects were still occurring within the mill and therefore could be demonstrated. During this process it was reiterated that due to technological improvements the majority of these faults would not occur anymore. The list of faults from The Systematic Training for Burlers and Menders manual (1970) is shown below (Table 2) with the faults that still occur at present day highlighted in green.

Table 2 here.

\section{Collecting fabric samples}

The informant was asked to collect samples that contained examples of manufacturing faults occurring within the mill. The collected pieces were then grouped together depending on the weave pattern and the fault type.

1. Characterising the faults 
Each defect was then classified in terms of the type of fault, for which a mending technique was applicable and how it was applied for different weave patterns. The mending techniques were categorised into mending, drawing, removing knots and finishing.

\section{Planning the filming}

A filming sequence Fig. 3 was then determined and used to facilitate and guide the filming process.

\section{Figure 3 here.}

The instructional section was expanded by adding illustrative animated diagrams that supported the informant's guidance in mending techniques. The introductory slides were signposts to help viewers assimilate the info, through clarifying the structure. Certain segments had additional captions to give brief explanations that would maximise clarity. Transitions were placed between the segments adding fade in and fade out effects for both visual and audio parts to provide smooth flow between the divisions.

\section{Designing and producing instructional diagrams}

As the documented mending instructions were evaluated, it became apparent that the faults and techniques were difficult to see clearly for a non-expert. Also, with the progression of filmed sequences, the demonstrations of techniques would move forward at a predetermined pace, forcing the audience to shift their focus to the new pieces of information. This could cause difficulties in remembering the previous instructional steps (Ganier, Vries, 2016). This revealed a need to develop a visualisation tool that would help to dissect and explain the weave structure in a slow and clear manner.

The visual tool was developed using two dimensional woven structure diagrams. These were adapted to mimic the structural representation of faults within the pattern structures and to simulate the step by step stitching actions taken to correct them.

Ordinarily, there are two common methods to represent weave structures: using linear diagrams and canvas diagrams. The former method illustrates warp yarns through vertical lines and weft yarns using horizontal lines Fig. 4. The latter, 
canvas technique, employs a squared paper method where each vertical space represents a warp thread, and each horizontal space represents a weft thread, this system is commonly used in design, drafting and peg plans (Gokarneshan, 2004).

\section{Figure 4 here.}

Initially, a commercial CAD package was employed to create graphical illustrations of weave structures. This proved to be problematic as the weave patterns could not be simulated to create a cloth like appearance, representing the pattern structure in an oversimplified way. Also, the commercial package did not allow the simulation of faults within the pattern structure Fig. 5.

\section{Figure 5 here.}

Instead of designing diagrams using a commercial CAD software, two linear diagram templates ( $1 \times 1$ plain weave and $2 \times 2$ twill weave) were used to develop appropriate diagrams for each demonstrated weave type and fault. This type of representation was found more suitable as linear diagrams showed a closer likeness to a physical weave structure.

These digital manipulations were achieved using CAD technologies, Photoshop and InDesign specifically. Each fault was represented through a linear diagram of a specific weave pattern Fig. 6 . The mending process was demonstrated by highlighting the working yarn with a contrasting colour and creating a diagram for each instructional step Fig. 7. The diagrams were arranged in sequences to create visual mending animations for each fault.

\section{Figure 6 here.}

\section{Figure 7 here.}

\section{Discussion}

The use of primary and secondary research addressed two leading matters concerning this study. Firstly, it provided a historical, social and technological context to understand the mending role within the manufacturing setting and, secondly, it supplied theoretical and practical principles that could be applied in designing and producing an educational tool for woven textile mending. 
The qualitative data collected using the semi-structured interview and the recordings of mending techniques was analysed through studying the content and categorising the information to expose the emerging themes. The key points were extracted, evaluated and compared while drawing parallels to the secondary research sources. After a thorough analysis of the primary data, certain themes emerged, which also correspond with the existing academic research and theories.

\section{Teaching through the expert learner}

Following Wood's (2009) research on craft elicitation through the expert learner, the filmed material aimed to capture the process of informant trying to teach a trainee. This was done with the intention to figure out how the presence of the trainee during the skill elicitation process could help with explaining the mending process to other learners (Wood et al., 2009). Four videos were compared to assess if there was any difference in how the informant provided mending instructions with and without the participation of the trainee. The first two videos were concerned with demonstrating how to mend the missing pick in a $2 \times 2$ twill fabric, while the second pair of recordings demonstrated how to draw the yarn in through the fabric.

The evaluation revealed that even though the informant was exceptionally good at describing and demonstrating mending techniques on her own, she managed to give more detailed explanations while describing the methods to the trainee. It was noticed that during the demonstrations the informant's actions were efficient, precise and appeared straightforward due to her movements being embedded in her muscle memory. Consequently, even though she was verbally explicit about every single step in her execution, she did not encounter any problematic points and therefore could not explain them. However, once the trainee attempted the same mending techniques, she was struggling with the simplest tasks, such as threading a needle, mainly because the activity was new to her.

Through observing the learner's actions, movements, and the moments that involved hesitation, the informant was able to provide more explicit instructions by pointing out how to hold the fabric, the needle, and the burlers. During the informant's own demonstration, she simply threaded the needle and proceeded 
with the task, making it seem like a fairly insignificant and simple action. However, seeing the trainee struggling with the task of threading, the informant showed a whole new technique, which previously was omitted as it was probably deemed to be too self-explanatory. Noticing the trainee's movements, the informant simplified the task by breaking it into mini steps: first, wrapping the thread around the needle, then forming the yarn into a loop and holding it with the thumb and the forefinger, and finally, pushing the loop of the yarn through the eye of the needle.

\section{Learning through observation and action}

The informant had learned her craft by sitting and watching her mother work rather than through an apprenticeship. She explained that the training process would usually involve about six months of working with somebody and roughly another six months of practicing it individually. This approach appears to be consistent with the suggestion that tacit knowledge is gained through experience of performing the actions and absorbing the principles (Wood et al., 2009). The same principle was also noticed in vernacular craft learning process where knowledge is demonstrated through context rather than theory (Reitan, 2014).

\section{Understanding the pattern, the fabric structure and the material}

In order to be a good mender, the informant emphasised the importance of being able to understand the structure of the woven pattern. She noted that during the training process she would encourage learners to follow the pattern rather than simply count the pick or the end yarns. For example, when explaining the herringbone pattern, she would draw in different colour yarns to emphasize the different pick patterns Fig.8.

Figure 8 here.

The informant strongly emphasised that mending and burling was to be done before the finishing process, because once the cloth was washed it would shrink and therefore the interference at that stage could ruin the cloth structure Fig.9.

\section{Figure 9 here.}


She then gave a demonstration of drawing technique, which was applied in the incidence of the wrong coloured yarn being mixed in within the weave. The technique involved securing the correct yarn to that of the incorrect colour and gently pulling it through until the correct yarn would replace the wrong one within the weave Fig.10. The informant explained that this action would not be possible if the cloth was already milled since the new yarn would not be able to enter the structure of the shrunk fabric.

Figure 10 here.

The informant revealed that usually, she could tell straight away if somebody had an aptitude for the job by judging their process of reflection and learning from mistakes. To illustrate, if the new trainee was able to notice his or her mistake and manage to trace it back to where it originated, it showed that the trainee was trying to understand and follow the pattern. This act of learner's own interaction with the material and reflection of the changes occurring within the piece was remarked by Torrell (2014) when referring to the cultivation of judgment. The action of reflection and evaluation was also emphasised in Wood's (2009) work where it was seen as the third stage of her learning framework. After the observational and action phases, learners were encouraged to assess their outcomes and repeat the process in order to improve (Wood et al., 2009). In Farrar and Trorey's (2008) research on learning dry stone walling, skill improvement was seen in the ability to avoid potential mistakes through recognising faults and using the gained experience to prevent their reoccurrence. Meanwhile, the informant suggested that the reflecting on and understanding the source of mending mistakes would help to develop the ability to recognise and follow the pattern of the weave structure.

\section{The development of visual pattern representation tool}

Two particular themes aided in the development of the instructional video tool: the need to understand the woven pattern and teaching through the expert learner. During this research project, it emerged that the ability to recognise the pattern was found to be a crucial element in learning mending skills. Therefore, the development of a suitable visual pattern representation system could be useful in trying to accelerate the learner's acquisition of pattern comprehension skills. To achieve this, linear weave diagrams were manipulated to visually 
express various weave structures. These diagrams were then animated in order to create a step by step graphic guidance that would illustrate the mending actions. The contrasting colours and the enlarged scale of the warp and weft yarns were used to clarify and emphasise the distinctive elements of the pattern structure.

\section{Evaluation of the effectiveness of the video}

The individuals selected to evaluate the educational tool were textile professionals but not experienced in mending. These were two lecturers in design technology at the University of Leeds and two senior members of staff at the mill. These participants were asked to provide comments on the content of the video regarding the data accuracy as well as its value for teaching tacit skills. The results were summarised, categorised and compared in terms of repetitions in observations as well as consistencies with primary and secondary data. Table 3 presents the findings from the four participants. The observations were grouped into themes and the keywords are highlighted. The findings referred to their experiences while attempting to mend as well as the perceptions of the overall effectiveness of the video.

\section{Table 3 here.}

The testing results exhibited recurring themes within the feedback which also corresponded with the previous analysis and findings from secondary research. The results were categorised into the following groups:

\section{Following the pattern}

The results strongly supported the notion that recognising and following the weave pattern was highly beneficial during the mending process as well as when assessing the accuracy. For example, Participant A found that she kept assessing the pick she was mending in terms of its position against the one above, aiming to make sure they wouldn't match Fig. 11.

\section{Figure 11 here.}

This constant re-valuation allowed her to instantly check if she made any mistakes and prevented from progressing with her work incorrectly. Therefore, the method of following the pattern automatically facilitates the act of reflection 
over one's work and builds on judgment abilities through interactions with fabric. Participant $B$ chose to follow the pattern in a similar way to Participant $A$, preferring to view the absent pick as a missing piece within the pattern unit Fig. 12.

\section{Figure 12 here.}

Meanwhile, Participant $C$ was employing the use of pattern visualisation in a different way, finding it more comprehensive to follow the arrangement of different coloured yarns stacked on the informant's needle Fig. 13.

\section{Figure 13 here.}

Participant B remarked that the visual pattern assessment, rather than the counting of stitches would train the intuition in mending: this would eventually help to increase the flow and the speed in one's work. This development of visual senses would help to internalise craft knowledge.

\section{Using the diagrams}

All testing participants welcomed the use of the diagrams in the educational video as they gave clear representations of the patterns and provided visual differentiation between the mending yarn and the rest of the structure through the use of colour contrast.

Participant $A$ thought that diagrams were particularly useful when trying to understand the harder weaves such as herringbone. She noted that if she needed to mend a herringbone pattern, she would rely on diagrams more strongly than on the explanation and the demonstration provided by the informant. This was due to the fact that the animated video used a contrasting coloured mending yarn as well as a scaled up pattern structure, which made the pattern more visible and the mending action easier to follow. Participant $B$ and Participant $D$ reiterated that the larger scale of the weave structure and distinctive colours were helpful in clearly presenting the weave pattern elements. Additionally, Participant B mentioned that the animation aspect and repetitive progression of mending steps helped to reinforce the action. Participant $C$ added that she liked the option of being able to pause the animation and see the progression of the already mended part and its relation to what yet had to be mended Fig. 14 . 


\section{Figure 14 here.}

All the participants expressed that the diagram showing different picks in the herringbone weave enabled them to comprehend the system and the relationships between the picks within the structure. Participant $B$ remarked that the presence of diagrams accompanied by the informant's demonstration helped to accelerate one's understanding of the weave structures. What's more, he thought that the diagrams would be very effective in training the eye to spot the errors in fabric. He noticed that after analysing the fault, it was easier to understand how the corrected yarn should appear within the pattern Fig. 15. Overall, the testing results confirmed that using still and animated diagrams served as an effective tool in teaching woven pattern structure and mending techniques as well as fault analysis.

\section{Figure 15 here.}

\section{Learning through the trainee}

Both Participant B and Participant C expressed that observing somebody else learn the same technique and struggle or make mistakes while doing helped to understand the process in a better way. Participant $C$ noted that since the informant's movements were embedded in her muscle memory, she did not make mistakes during her demonstration. This observation corresponded with the conclusions from the primary data analysis as well as Wood's remarks on knowledge elicitation through the expert learner by building 'bridges' in understanding. Consequently, testing results supported that the trainee's participation in the instructional video was an effective method to teach mending skills.

\section{The visibility of the mending piece}

It emerged that the part that caused most difficulties for all testing participants was the small scale of the weave structure as all of them were struggling to see the picks and ends, particularly when the darker colours were involved. The leading informant noted that, based on her experience and observations, it was possible to train eyes to adjust to the small scale of the pattern, however she mentioned some menders simply prefer to wear magnifying glasses or goggles. 


\section{Conclusions}

Using the research findings, an instructional video was developed in order to document and display the mending craft practice in a format that would endure and be accessible to anybody who wished to learn. The data findings revealed two particular themes that were fundamental in ensuring that effective methods were used to develop the video tool: first, the need to train woven pattern comprehension and second, achieving improved instructions with the presence of the trainee during the tacit knowledge elicitation process.

As the result, a visual tool was developed using two dimensional woven structure diagrams. They were adapted to mimic the structural representation of faults within the pattern and to simulate the step by step stitching actions taken to correct them. These were added to support the informant's demonstrations and explanations in a video sequence. Additionally, the sequences of the informant teaching a trainee were incorporated into the educational video structure as they were found to reveal additional instructions and situations involving potential problem points. The instructional video is now available in the mill shop for any interested parties and also available for all mill employees.

The instructional video is also now being used in the School of Design as Formatted: Font: Bold an educational tool for undergraduate and postgraduate textile students. One of the latter group has been sufficiently inspired to undertake a project on the development of a new type of darning mushroom.

\section{References}

1. Akyildiz Scissor (2015), "Ball Point Needles / Weaving Needles", available at: http://www.akyildizmakas.com/cimbiz-dokumaci-ignesi.html, (accessed 20 August, 2016);

2. Babbage, J. (2010), "Last Craftsmen Fight to Save Their Trades", available at: http://news.bbc.co.uk/1/hi/business/8586172.stm, (accessed 16 August 2016);

3. Farrar, N. and Trorey, G. (2008), "Maxims, tacit knowledge and learning: developing expertise in dry stone walling", Journal of Vocational Education \& Training, Vol. 60, pp. 35-48; 
4. Ganier, F. and Vries, P. (2016), "Are instructions in video format always better than photographs when learning manual techniques? The case of learning how to do sutures", Learning and Instruction, Vol. 44, pp. 87-96;

5. Hammersley, M. (2004). "Teaching qualitative methodology: craft, profession or bricolage", Seale, C.; Gobo, G.; Gubrium, J. F. and Silverman, D. (Ed.), Qualitative Research Practice, Sage, London, pp. 549-560;

6. Holmberg, A. (2013), "Masters and Apprentices of Textile Craft", Techne Series, Vol. 20, pp. 20-32;

7. Horrocks, A. R. and Anand, S. C. (2000), Handbook of Technical Textiles, Woodhead Publishing Limited, Cambridge;

8. Karmakar, S. R. (1999). Chemical Technology in the Pre-Treatment Processes of Textiles, 1st Edition, Elsevier, Amsterdam;

9. Knoblauch, H. and Schnettler, B. (2012), "Videography: Analysing Video Data as a 'Focused' Ethnographic and Hermeneutical Exercise", Qualitative Research, Vol. 12, pp. 334-356;

10. Koskinen, A.; Seitamaa-Hakkarainen, P. and Hakkarainen, K. (2015), "Interaction and Embodiment in Craft Teaching", Techne Series, Vol. 22, pp. 59-72;

11. King, W. E. and Lester, J. H. (1932), "The Testing of Textiles - with Special Reference to the Investigation of Defects in Yarns and Fabrics", Journal of the Textile Institute Proceedings, Vol. 23, pp.102-112;

12. Lindwall, O. and Ekström, A. (2012), "Instruction-in-Interaction: The Teaching and Learning of a Manual Skill", Human Studies, Vol. 35, pp. 27-49;

13. Lyness, J. S. and Murphy, W. (1955), "Control of Quality in Weaving", Journal of the Textile Institute Proceedings, Vol. 46, pp. 201-208;

14. Pauwels, L. and Margolis, E. (2011), The SAGE Handbook of Visual Research Methods, Sage Publications Ltd, London;

15. Reitan, J. B. (2014), "Learning by Watching Vernacular Iñupiaq-Inuit Design Learning as Inspiration for Design Education", Techne Series, Vol. 21, pp. 1-20;

16. Roberts, P. and Priest, H. (2010), Healthcare Research: a Textbook for Students and Practitioners, John Wiley \& Sons Ltd, Chichester; 
17. Rusu, A. (2011), "Traditional textile art between sustainability and economic growth", Review of Applied Socio-Economic Research, pp. 160-166;

18. Shrum, W.; Duque, R.; Brown, T. (2005), "Digital Video as Research Practice: Methodology for the Millennium", Journal of Research Practice, Vol.1;

19. Stewart, M. (2009). Punchneedle The Complete Guide, Krause Publications, Cincinnati;

20. The Wool, Jute and Flax Industry Training Board (1975), Systematic Training for Burlers and Menders, Wool, Jute and Flax Industry Training Board, Shipley;

21. Torell, V. B. (2014), "Knowledge in action in weaving", Techne Series, Vol. 21, pp. 22-37;

22. Tracy, S. J. (2013), Qualitative Research Methods Collecting Evidence, Crafting Analysis, Communicating Impact, John Wiley \& Sons Ltd, Chichester;

23. Tung, F. W. (2012), "Weaving with Rush: Exploring Craft-Design Collaborations in Revitalizing a Local Craft", International Journal Design, Vol. 6, pp. 71-84;

24. Wood, N. (2009), "The New Journeyman: The Role of an Expert Learner in Eliciting and Transmitting Skilled Knowledge" paper presented at Undisciplined! Design Research Society Conference, 16-19 July 2008 Sheffield Hallam University, Sheffield, available at: http://shura.shu.ac.uk/505/ (accessed 1 September 2016);

25. Wood, N.; Rust, C.; Horne, G. (2009), "A Tacit Understanding: The Designer's Role in Capturing and Passing on the Skilled Knowledge of Master Craftsmen", International Journal of Design, Vol. 3, pp. 65-78;

26. Yee, J. and Bremner, C. (2011), "Methodological bricolage: What does it tell us about design?" paper presented at the Doctoral Design Education Conference, 23-25 May 2011, Hong Kong Polytechnic, Hong Kong, available at: http://nrl.northumbria.ac.uk/8822/ (accessed 5 September 2016). 


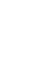


Table 1. Summarised enquiry themes that were explored during the semistructured interview.

\begin{tabular}{|l|l|}
\hline 1. The informant's background & $\begin{array}{l}\text { The intention was to understand the } \\
\text { reasons for choosing mending as a } \\
\text { vocation as well as identify her } \\
\text { learning process, experience and } \\
\text { feelings towards the job. }\end{array}$ \\
\hline 2. The faults & $\begin{array}{l}\text { The questions aimed to investigate } \\
\text { the nature and the origin of the fabric } \\
\text { faults that occur within the mill. }\end{array}$ \\
\hline 3. Textile structure & $\begin{array}{l}\text { The goal was to identify how the } \\
\text { fabric structure influenced the } \\
\text { mending process. }\end{array}$ \\
\hline 4. Training & $\begin{array}{l}\text { The aim was to learn about the } \\
\text { teaching methods and techniques } \\
\text { used train new menders within the } \\
\text { mill. }\end{array}$ \\
\hline
\end{tabular}


Table 2. Fault analysis.

\begin{tabular}{|c|c|c|c|}
\hline NAME & APPEARANCE & ACTION & $\begin{array}{c}\text { OTHER } \\
\text { COMMENTS }\end{array}$ \\
\hline 1. Stitching. & $\begin{array}{l}\text { Warp or weft } \\
\text { threads not worked } \\
\text { in. }\end{array}$ & $\begin{array}{l}\text { Cut floating } \\
\text { threads, mend in, } \\
\text { ensuring pattern } \\
\text { correct. }\end{array}$ & \\
\hline 2. Wrong draft. & $\begin{array}{l}\text { Pattern incorrect, } \\
\text { end in wrong place. }\end{array}$ & $\begin{array}{l}\text { Draw in or remove } \\
\text { and mend in. }\end{array}$ & $\begin{array}{l}\text { May look at first } \\
\text { sight like } \\
\text { missing/broken } \\
\text { end. }\end{array}$ \\
\hline 3. Curls. & $\begin{array}{l}\text { Loops in cloth } \\
\text { either warp or weft. }\end{array}$ & $\begin{array}{l}\text { See Breakdown } 10 . \\
\text { Separate, cut or } \\
\text { pull onto back or } \\
\text { side. }\end{array}$ & \\
\hline 4. Broken end. & $\begin{array}{l}\text { Pattern broken by } \\
\text { missing warp end. }\end{array}$ & $\begin{array}{l}\text { Detect and mend in } \\
\text { correct yarn } \\
\text { ensuring correct } \\
\text { tension. }\end{array}$ & $\begin{array}{l}\text { Loom has } \\
\text { continued weaving } \\
\text { after end broke. } \\
\text { When eventually } \\
\text { found, weaver tied } \\
\text { in beating, tried to } \\
\text { keep it at same } \\
\text { tension. }\end{array}$ \\
\hline 5. Broken pick. & $\begin{array}{l}\text { Pattern broken by } \\
\text { missing weft } \\
\text { threads. }\end{array}$ & $\begin{array}{l}\text { Detect and mend in } \\
\text { correct yarn } \\
\text { ensuring right } \\
\text { tension. }\end{array}$ & $\begin{array}{l}\text { If detected by } \\
\text { weaver, broken } \\
\text { pick is in most } \\
\text { cases removed and } \\
\text { replaced by } \\
\text { weaver. }\end{array}$ \\
\hline 6. Wrong & Different colour or & Remove and & Mistake by warper \\
\hline
\end{tabular}




\begin{tabular}{|c|c|c|c|}
\hline warp/weft. & $\begin{array}{l}\text { count of yarn in } \\
\text { cloth. }\end{array}$ & replace. & or weaver. \\
\hline 7. Weft bar (thin). & Weft slightly apart. & $\begin{array}{l}\text { Report to } \\
\text { supervisor. }\end{array}$ & $\begin{array}{l}\text { Caused by faulty } \\
\text { loom, mistake in } \\
\text { resetting by weaver } \\
\text { or yarn faults. }\end{array}$ \\
\hline 8. Weft bar (thick) & $\begin{array}{l}\text { Weft crammed } \\
\text { together. }\end{array}$ & $\begin{array}{l}\text { Report to } \\
\text { supervisor. }\end{array}$ & $\begin{array}{l}\text { Caused by faulty } \\
\text { loom, mistake in } \\
\text { resetting by weaver } \\
\text { or yarn faults. }\end{array}$ \\
\hline 9. Trailer. & $\begin{array}{l}\text { Thick line in weft } \\
\text { usually from } \\
\text { selvedge. }\end{array}$ & $\begin{array}{l}\text { Draw trailing and } \\
\text { clear. Retension } \\
\text { cloth. }\end{array}$ & $\begin{array}{l}\text { If not eliminated } \\
\text { becomes problem } \\
\text { in finishing. }\end{array}$ \\
\hline 10. Tight end. & $\begin{array}{l}\text { Line warpways in } \\
\text { cloth. May appear } \\
\text { thin. }\end{array}$ & $\begin{array}{l}\text { Remove and draw } \\
\text { in new yarn. }\end{array}$ & $\begin{array}{l}\text { If length great, } \\
\text { draw in lengths of } \\
6 " \text { at most, } \\
\text { repeating as } \\
\text { required. }\end{array}$ \\
\hline 11. Slack end. & Line down cloth. & $\begin{array}{l}\text { Restore tension if } \\
\text { associated with } \\
\text { broken end starting } \\
\text { from where stock } \\
\text { appears. Leave } \\
\text { loop every foot or } \\
\text { so. Ensure correct } \\
\text { tension. }\end{array}$ & Felt as rough line. \\
\hline 12. Button. & $\begin{array}{l}\text { Lump or snarl of } \\
\text { fibres or fluff } \\
\text { wrapped into tight } \\
\text { ball. }\end{array}$ & $\begin{array}{l}\text { 1. Where formed } \\
\text { round knot, pull } \\
\text { clear of cloth } \\
\text { and gently }\end{array}$ & $\begin{array}{l}\text { If particularly bad, } \\
\text { might be easier to } \\
\text { simply pull button } \\
\text { clear and mend }\end{array}$ \\
\hline
\end{tabular}




\begin{tabular}{|c|c|c|c|}
\hline & & $\begin{array}{l}\text { separate out } \\
\text { and draw off } \\
\text { fibres. Can } \\
\text { result in finding } \\
\text { trails or original } \\
\text { knot. } \\
\text { 2. Where felted } \\
\text { round particular } \\
\text { strand of yarn, } \\
\text { carefully cut } \\
\text { through to } \\
\text { remove. }\end{array}$ & fault thus created. \\
\hline 13. Thin yarn. & $\begin{array}{l}\text { Yarn thin, may } \\
\text { appear as break in } \\
\text { pattern. }\end{array}$ & Draw in fresh yarn. & $\begin{array}{l}\text { Delicately, if thin } \\
\text { through lack of } \\
\text { fibres; more easily } \\
\text { if thin because of } \\
\text { hard twist. }\end{array}$ \\
\hline 14. Straw. & $\begin{array}{l}\text { Small pieces of } \\
\text { vegetable material } \\
\text { drawn into cloth or } \\
\text { yarn. }\end{array}$ & $\begin{array}{l}\text { Remove with } \\
\text { burling } \\
\text { irons/pickers. }\end{array}$ & \\
\hline 15. Slub. & $\begin{array}{l}\text { Short piece of thick } \\
\text { normally less than } \\
2 \text { " long. }\end{array}$ & $\begin{array}{l}\text { Grasp centre of } \\
\text { slub, lift until piece } \\
\text { carrying waste is } \\
\text { clear, pick of } \\
\text { excess fibres. }\end{array}$ & 8 \\
\hline
\end{tabular}

Table 3. Summarised results of testing the effectiveness of the educational tool through novice learners.

\begin{tabular}{|l|l|l|l|l|}
\hline Name & Participant A & Participant B & Participant C & Participant D \\
\hline
\end{tabular}




\begin{tabular}{|c|c|c|c|c|}
\hline $\begin{array}{l}\text { Were they } \\
\text { able to mend } \\
\text { the sample? }\end{array}$ & Yes & Yes & Yes & Yes \\
\hline $\begin{array}{l}\text { What was the } \\
\text { most helpful? }\end{array}$ & $\begin{array}{l}\text { 1. The } \\
\text { diagrams } \\
\text { 2. Following the } \\
\text { pattern } \\
\text { 3. The structure } \\
\text { of seeing the } \\
\text { actual fabric } \\
\text { and correcting } \\
\text { action first } \\
\text { and the } \\
\text { diagram later } \\
\text { helped } \\
\text { understanding } \\
\text {. } \\
\text { Multiple } \\
\text { viewing of } \\
\text { the video }\end{array}$ & $\begin{array}{l}\text { 1. The diagrams } \\
\text { 2. Following the } \\
\text { pattern } \\
\text { 3. Seeing the } \\
\text { actual process } \\
\text { first and the } \\
\text { diagram later } \\
\text { helped } \\
\text { understanding } \\
\text { and reinforced } \\
\text { the action } \\
\text { 4. Seeing the } \\
\text { trainee making } \\
\text { mistakes } \\
5 . \text { Multiple } \\
\text { viewing of the } \\
\text { video }\end{array}$ & $\begin{array}{l}\text { 1. The } \\
\text { diagrams } \\
\text { 2. Following the } \\
\text { pattern } \\
\text { 3. Seeing the } \\
\text { order of the yarn } \\
\text { colours on the } \\
\text { informant's } \\
\text { needle } \\
\text { 4. The } \\
\text { structure of } \\
\text { seeing the } \\
\text { instructions first } \\
\text { and the diagram } \\
\text { later helped to } \\
\text { understand and } \\
\text { reinforce the } \\
\text { action } \\
\text { 5. Seeing the } \\
\text { trainee making } \\
\text { mistakes } \\
6 . \text { Multiple } \\
\text { viewing of the } \\
\text { video }\end{array}$ & $\begin{array}{l}\text { 1. The diagrams } \\
\text { 2. Following the } \\
\text { pattern } \\
\text { 3. Moving the } \\
\text { fabric with the } \\
\text { other hand in } \\
\text { accordance with } \\
\text { the movements } \\
\text { of the needle } \\
\text { 4. The use of } \\
\text { lightbox in the } \\
\text { video to see the } \\
\text { fault }\end{array}$ \\
\hline $\begin{array}{l}\text { Why was the } \\
\text { diagram } \\
\text { helpful? }\end{array}$ & $\begin{array}{l}\text { 1. Colour } \\
\text { contrast } \\
\text { 2. Bigger scale } \\
\text { 3. Slower speed } \\
\text { 4. Can pause }\end{array}$ & $\begin{array}{l}\text { 1. Colour } \\
\text { contrast } \\
\text { 2. Bigger scale } \\
\text { 3. Slower speed } \\
\text { 4. Repetitive }\end{array}$ & $\begin{array}{l}\text { 1. Visibility } \\
\text { 2. Can pause } \\
\text { and } \\
\text { compare the } \\
\text { progress }\end{array}$ & $\begin{array}{l}\text { 1. Showed the } \\
\text { pattern } \\
\text { clearly } \\
\text { 2. Helped to } \\
\text { understand }\end{array}$ \\
\hline
\end{tabular}




\begin{tabular}{|l|l|l|l|l|}
\hline \multirow{4}{*}{} & $\begin{array}{c}\text { and compare } \\
\text { the progress }\end{array}$ & $\begin{array}{c}\text { pace of the } \\
\text { animation } \\
\text { 5. Schematic } \\
\text { representation } \\
\text { 6. Helped to } \\
\text { understand } \\
\text { the pattern }\end{array}$ & $\begin{array}{r}\text { 3. Helped to } \\
\text { understand } \\
\text { the pattern }\end{array}$ & the pattern \\
\hline What was the & $\begin{array}{l}\text { Small scale of } \\
\text { hardest part? }\end{array}$ & $\begin{array}{l}\text { Small scale of } \\
\text { the yarns in the } \\
\text { the yarns in the } \\
\text { fabric }\end{array}$ & $\begin{array}{l}\text { Small scale of } \\
\text { the yarns in the } \\
\text { fabric }\end{array}$ & $\begin{array}{l}\text { Small scale of } \\
\text { the yarns in the } \\
\text { fabric }\end{array}$ \\
\hline
\end{tabular}




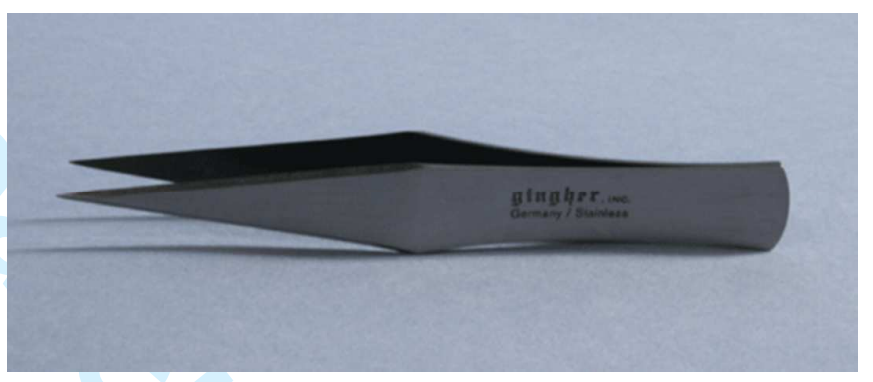

Figure 1. Burling irons 


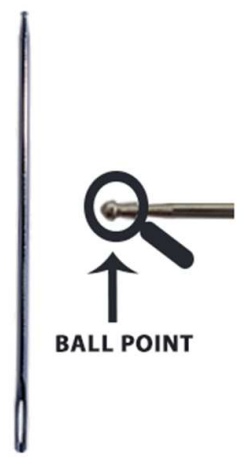

Figure 2. Ball point needle 


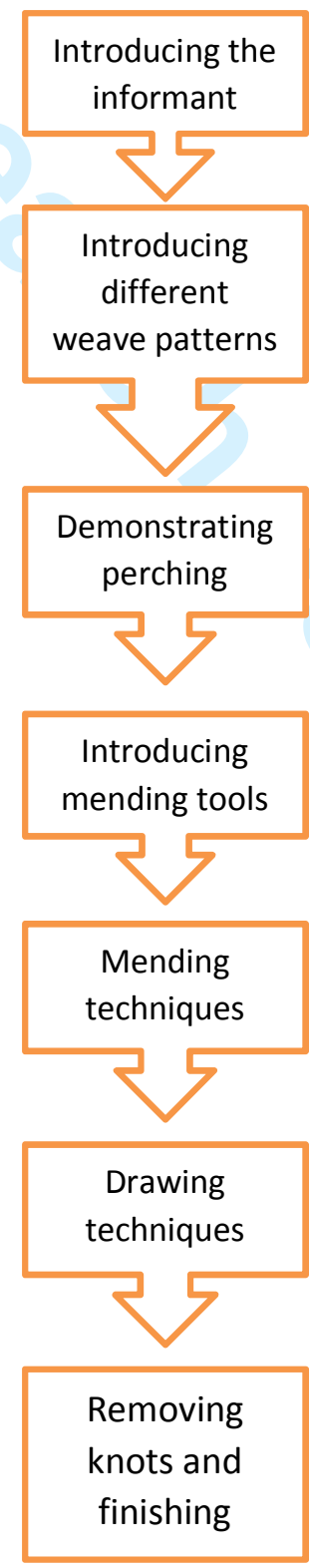

Figure 3. Flow chart of the filming sequence. 


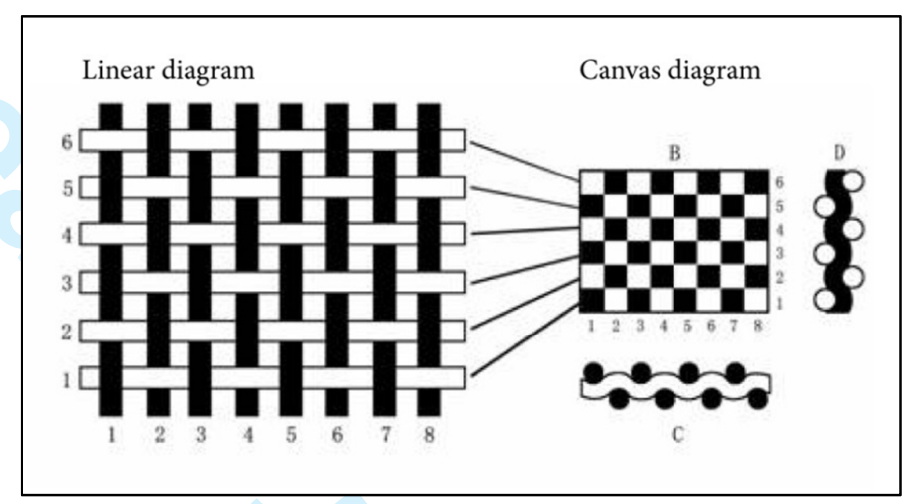

Figure 4. Linear and canvas weave diagrams 
Bird's eye pattern structure

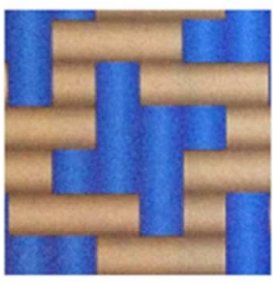

a)

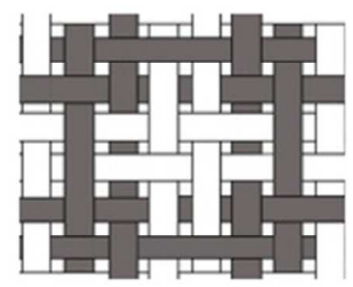

b)

Figure 5. Comparison of visual representation of bird's eye pattern using a) Easy Weave CAD software b) Linear diagram template, manipulated using the Photoshop. 


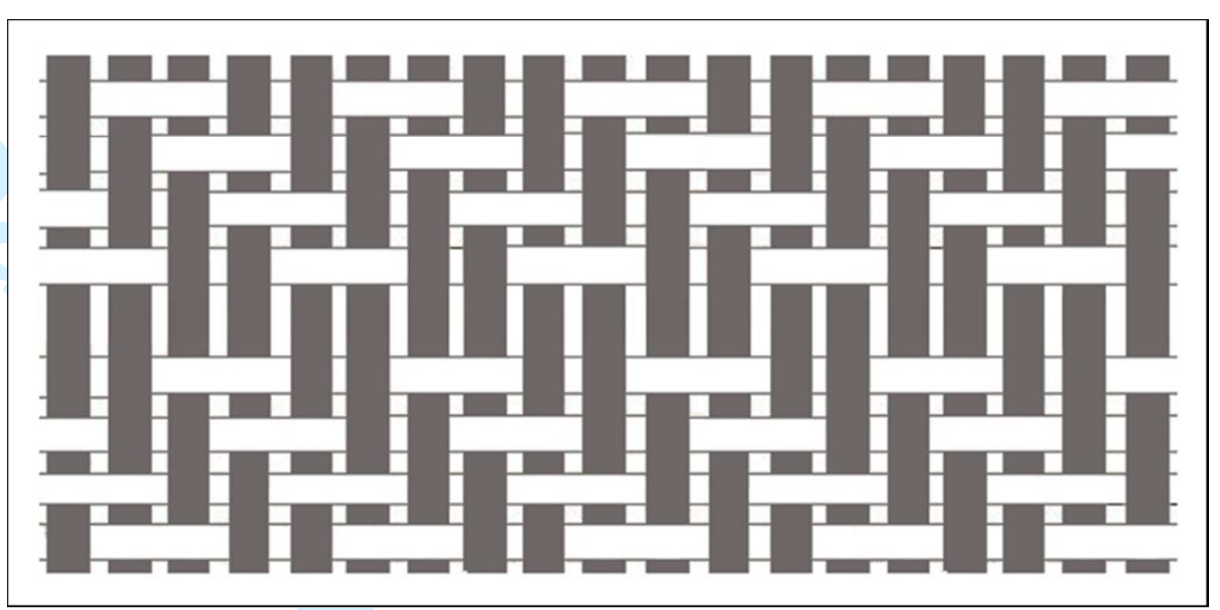

Figure 6. Missing end in a $2 \times 2$ twill weave linear diagram. 


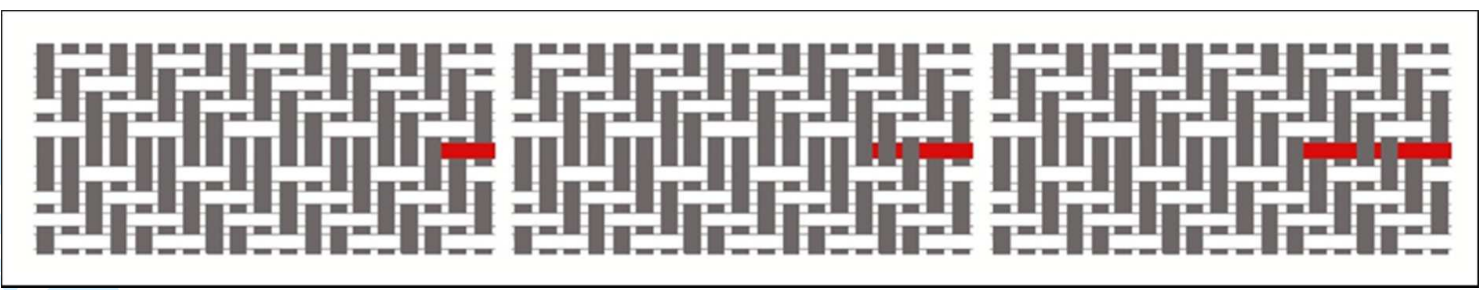

Figure 7. Linear diagrams for step by step mending action in a 2x2 twill weave. 


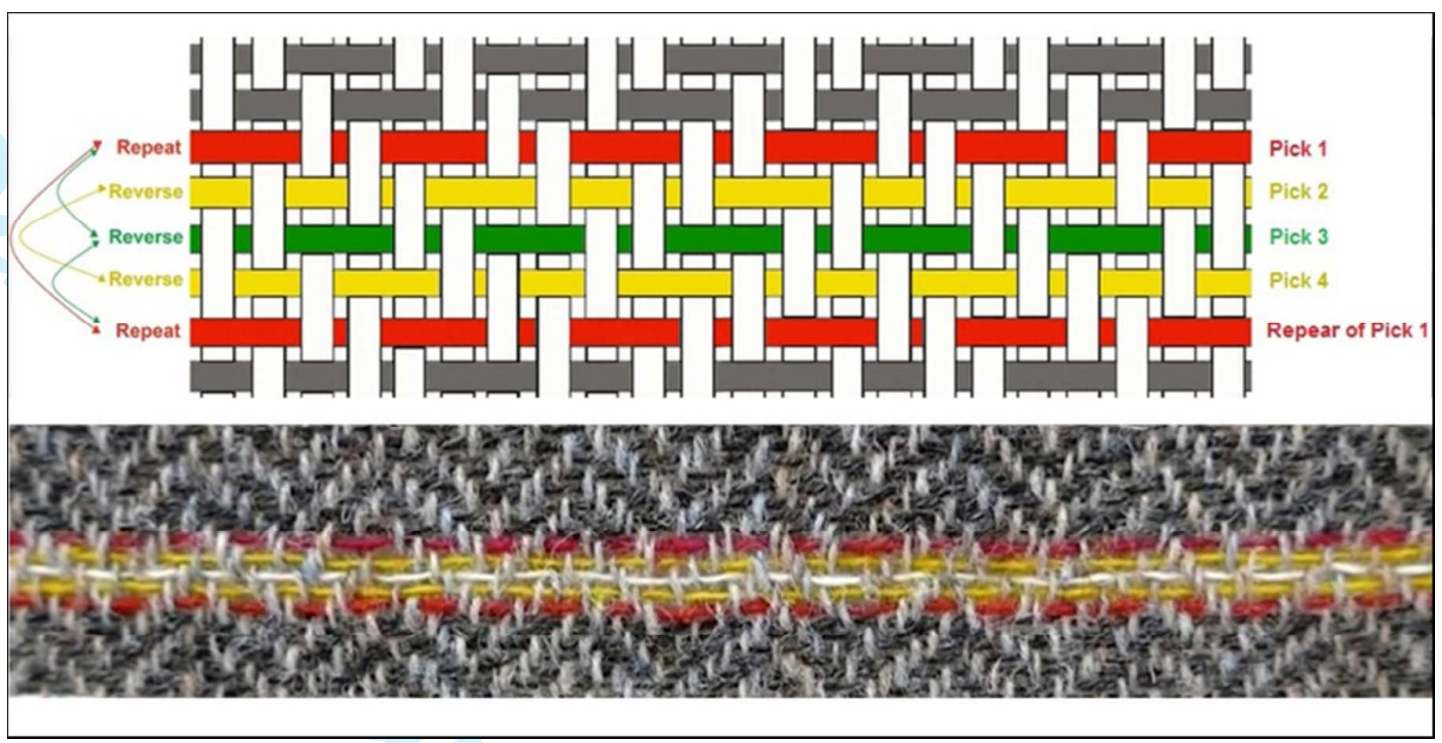

Figure 8. The diagram shows the different picks within the herringbone weave and the relationship between them. The picture below highlights different picks within the fabric. 


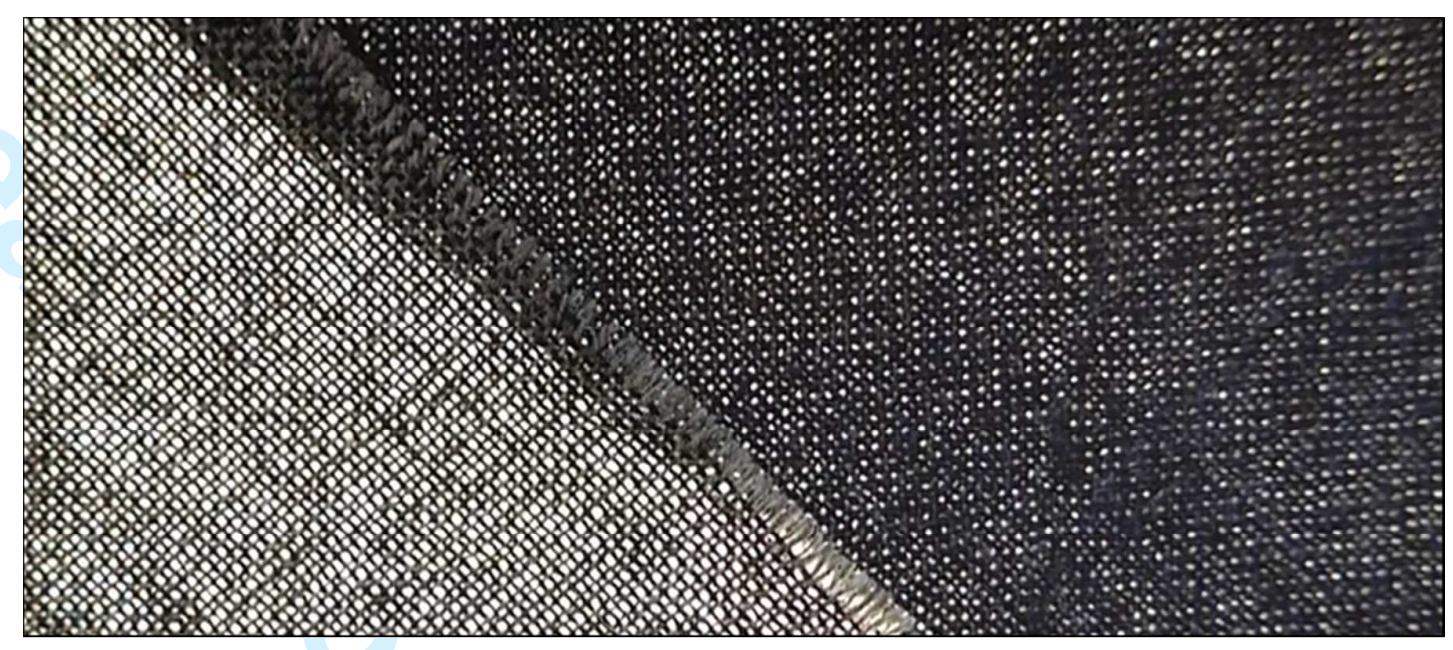

Figure 9. The difference between raw and milled cloth. 


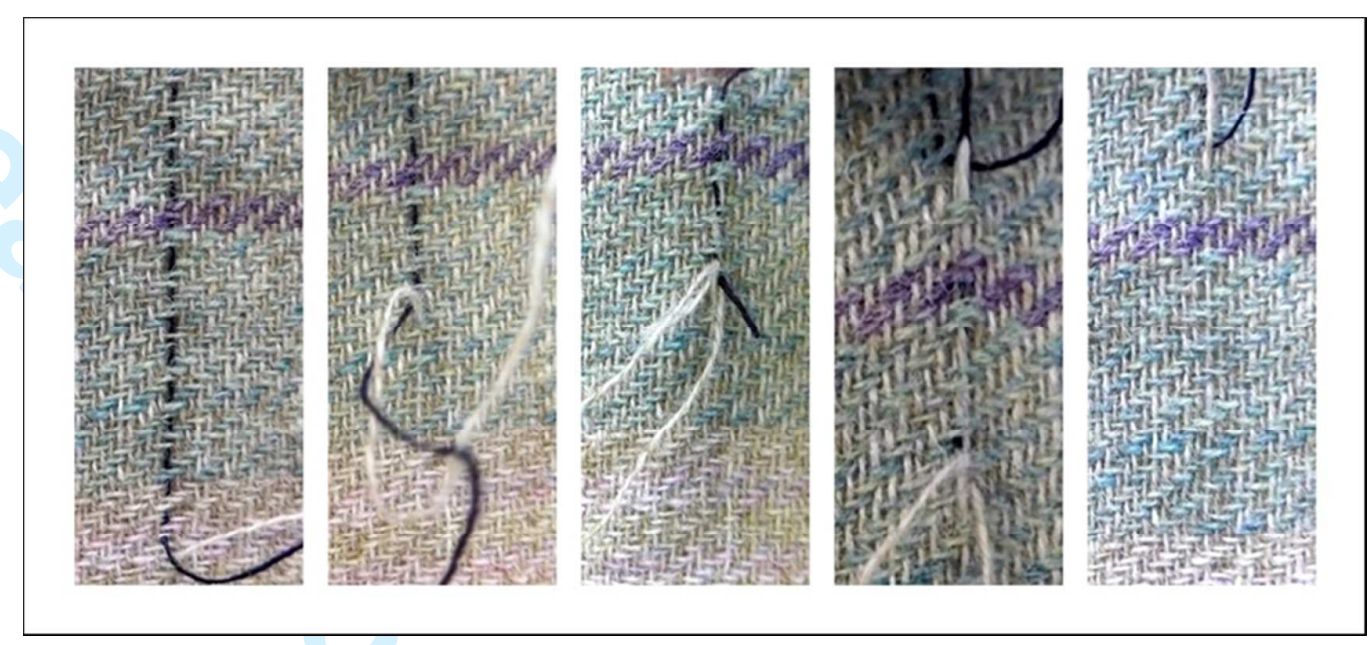

Figure 10. The stages of drawing technique. 


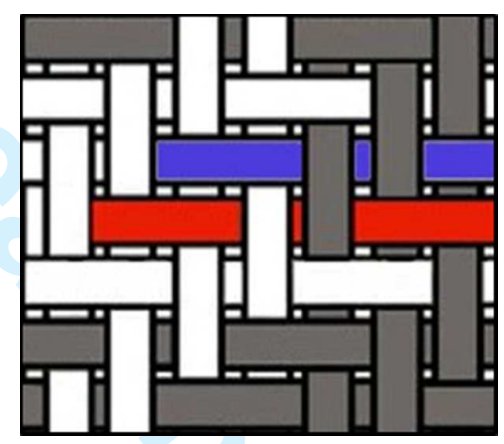

Figure 11. The red pick should not match the blue one but form a diagonally stacked pattern. 


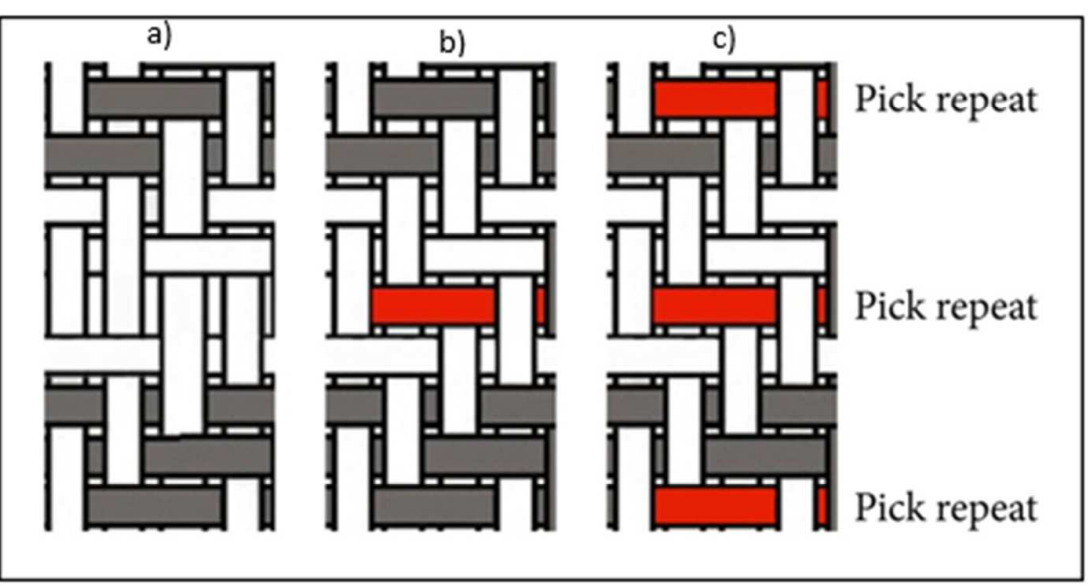

Figure 12. Image a) shows a pattern unit with a missing pick. Image b) demonstrates a complete pattern unit. Image c) highlights the pattern repeat every four picks. 


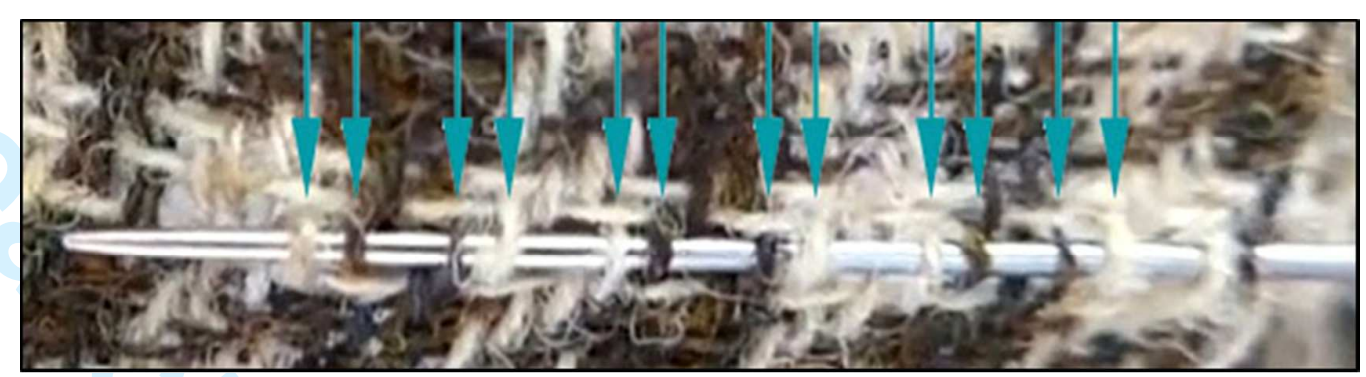

Figure 13. Following the pattern of yarn colour on the needle. 


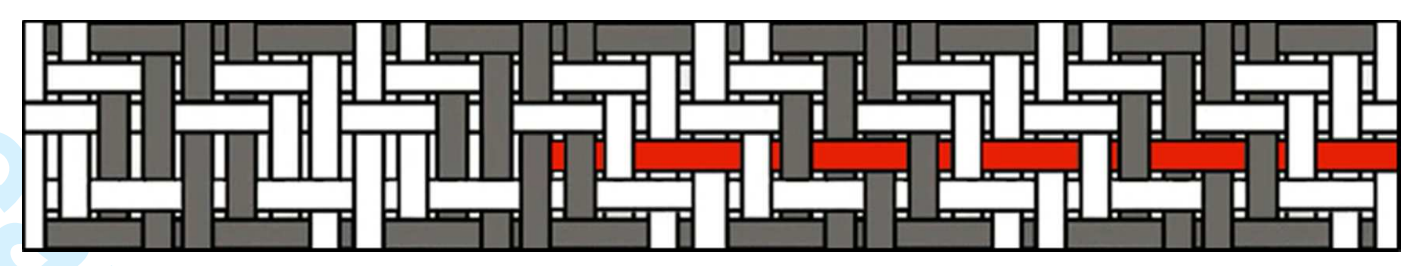

Figure 14. Demonstrating the progression of mending through the use of contrasting colour. 


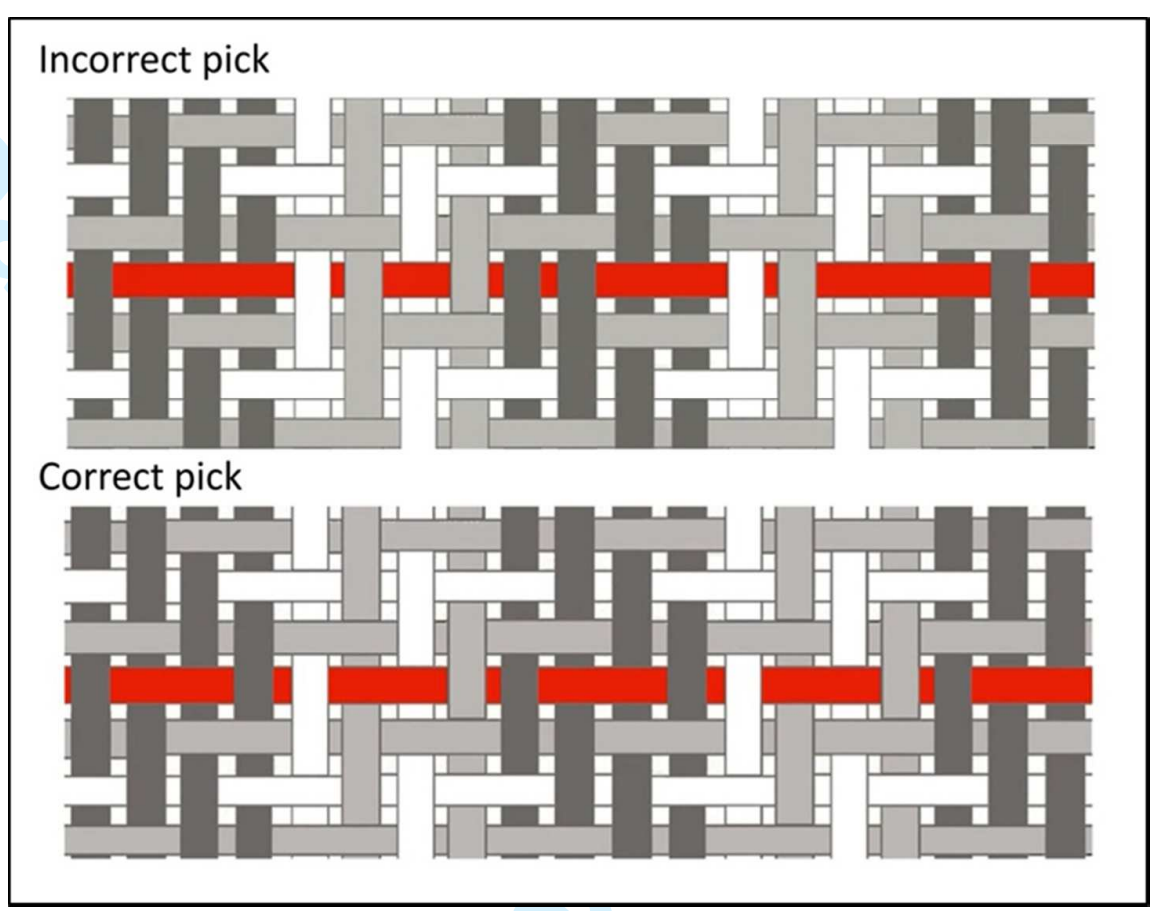

Figure 15. Using diagrams to understand the fault and how to correct it. 